\title{
Connecting two-component regulatory systems by a protein that protects a response regulator from dephosphorylation by its cognate sensor
}

\author{
Akinori Kato and Eduardo A. Groisman ${ }^{1}$ \\ Department of Molecular Microbiology, Howard Hughes Medical Institute, Washington University School of Medicine, \\ St. Louis, Missouri 63110, USA
}

\begin{abstract}
A fundamental question in signal transduction is how an organism integrates multiple signals into a cellular response. Here we report the mechanism by which the Salmonella PmrA/PmrB two-component system responds to the signal controlling the $\mathrm{PhoP} / \mathrm{PhoQ}$ two-component system. We establish that the PhoP-activated PmrD protein binds to the phosphorylated form of the response regulator PmrA, preventing both its intrinsic dephosphorylation and that promoted by its cognate sensor kinase PmrB. This results in PmrA-mediated transcription because phosphorylated PmrA exhibits higher affinity for its target promoters than unphosphorylated PmrA. A PmrD-independent form of the PmrA protein was resistant to PmrB-catalyzed dephosphorylation and promoted transcription of PmrA-activated genes in the absence of inducing signals. This is the first example of a protein that enables a two-component system to respond to the signal governing a different two-component system by protecting the phosphorylated form of a response regulator.
\end{abstract}

[Keywords: PhoP; PhoQ; PmrA; PmrB; PmrD; protein phosphorylation; signal transduction]

Supplemental material is available at http://www.genesdev.org.

Received June 10, 2004; revised version accepted July 28, 2004.

The two-component system is the most prevalent form of signal transduction enabling bacteria to alter cellular behavior in response to environmental cues (Hoch and Silhavy 1995; Inouye and Dutta 2003). Typically, a twocomponent system consists of a sensor histidine kinase that responds to specific signals by altering the phosphorylated state of a cognate response regulator protein. Binding of a specific ligand promotes conformational changes in the sensor protein that can potentially alter three enzymatic activities: autophosphorylation from ATP, transfer of the phosphoryl group to its cognate regulator, and dephosphorylation of the phosphorylated cognate regulator (Stock et al. 2000). The vast majority of response regulators are DNA-binding transcription factors whose affinities for their target promoters are modulated by phosphorylation. Thus, by altering the phosphorylated state of a response regulator, a signal often modifies the gene expression profile of an organism.

The PmrA/PmrB two-component system of Salmonella enterica serovar Typhimurium governs inducible

${ }^{1}$ Corresponding author.

E-MAIL groisman@borcim.wustl.edu; FAX (314) 747-8228.

Article and publication are at http://www.genesdev.org/cgi/doi/10.1101/ gad.1230804. resistance to the antibiotic polymyxin B (Groisman et al. 1997; Wösten et al. 2000). The PmrA/PmrB system independently responds to two signals: $\mathrm{Fe}^{3+}$, which is sensed by the cognate sensor PmrB (Wösten et al. 2000), and low $\mathrm{Mg}^{2+}$, which is sensed by the noncognate sensor PhoQ (Fig. 1; García Véscovi et al. 1996). The low $\mathrm{Mg}^{2+}$ activation not only requires the PhoQ protein but also its cognate response regulator $\mathrm{PhoP}$, the PhoP-activated pmrD gene, as well as the PmrA and PmrB proteins (Kox et al. 2000). Expression of the $p m r D$ gene from a heterologous promoter bypasses the requirement for the PhoP and PhoQ proteins and for the low $\mathrm{Mg}^{2+}$ signal, but not for the PmrA and PmrB proteins, indicating that the role of the PhoP/PhoQ system in the low $\mathrm{Mg}^{2+}$ activation of PmrA-regulated genes is solely to promote expression of the pmrD gene, and that the $p m r D$ gene acts downstream of the PhoP/PhoQ system but upstream of (or at the same level as) the PmrA/PmrB system. The PmrD protein appears to control the PmrA/PmrB system at a posttranscriptional level, because expression of PmrAactivated genes was abolished in a $\operatorname{pmrD}$ mutant experiencing low $\mathrm{Mg}^{2+}$ even when the $\operatorname{pmr} A B$ genes were transcribed from the lac promoter (Kox et al. 2000).

In contrast to the low $\mathrm{Mg}^{2+}$ activation, $\mathrm{Fe}^{3+}$-promoted transcription of PmrA-regulated genes requires neither 


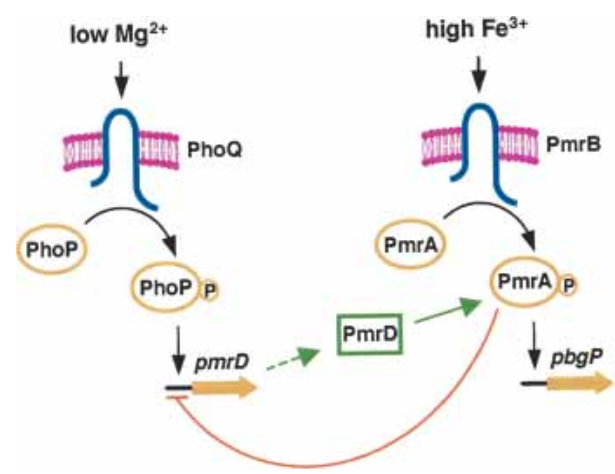

Figure 1. Model illustrating the regulatory interactions between the PhoP/PhoQ and PmrA/PmrB two-component systems and the PmrD protein. The PmrA protein promotes transcription of the $\operatorname{pbg} P$ gene during growth in low $\mathrm{Mg}^{2+}$ via the PhoP/PhoQ system, which turns on expression of the PhoPactivated PmrD protein, which, in turn, activates the PmrA/ PmrB system at a posttranslational level. The PmrB protein responds to $\mathrm{Fe}^{3+}$ by activating the PmrA protein independently of the PhoP/PhoQ system and PmrD protein, which promotes transcription of the $p b g P$ gene and represses transcription of the pmrD gene.

the PhoP/PhoQ system nor the pmrD gene, but it is dependent on the periplasmic $\mathrm{Fe}^{3+}$-sensing domain of the PmrB protein (Wösten et al. 2000). The pmrD gene is intimately interwoven into the circuitry of the PhoP/ PhoQ and PmrA/PmrB systems, because $p m r D$ transcription is not only activated in low $\mathrm{Mg}^{2+}$ in a $\mathrm{PhoP} /$ PhoQ-dependent manner (Kox et al. 2000), but it is also subjected to negative feedback regulation by the PmrA/ PmrB system in response to $\mathrm{Fe}^{3+}$ (Fig. 1; Kato et al. 2003). This indicates that Salmonella tightly regulates PmrD levels, possibly to prevent accumulation of activated PmrA protein.

In this study, we determined the mechanism by which the PmrD protein activates the PmrA protein, which expands the environments where Salmonella can express its polymyxin B resistance determinants. Using a series of in vitro and in vivo experiments, we establish that the PmrD protein specifically targets phosphorylated PmrA, protecting it from PmrB-promoted dephosphorylation. The PmrD protein provides the first example of a physiological connection between two-component regulatory systems resulting from protection of dephosphorylation of a response regulator.

\section{Results}

PmrD activates the PmrA/PmrB system at a postranslational level

The PmrA/PmrB system is encoded by the $\operatorname{pmrCAB}$ operon (Roland et al. 1993) and transcribed from two promoters: a PmrA-activated promoter located upstream of the $p m r C$ gene and a constitutive promoter present within the $\mathrm{pmrC}$ coding region (Fig. 2A; Gunn and Miller 1996; Soncini and Groisman 1996; Wösten and Groisman 1999; Lee et al. 2004). We reasoned that a $p m r D$ mutation might reduce the levels of the PmrA and PmrB proteins during growth in low $\mathrm{Mg}^{2+}$ because the $\mathrm{PmrD}$ protein activates the PmrA/PmrB system (Kox et al. 2000) and because activated PmrA positively regulates transcription of $p m r C A B$ operon. Indeed, lower amounts of both PmrA and PmrB proteins were produced by a pmrD null mutant than by the isogenic wild-type strain grown in low $\mathrm{Mg}^{2+}$ (Fig. 2B). Although these results demonstrated that a pmrD mutation does affect the levels of the PmrA and PmrB proteins, they suggested that a potential posttranslational activity of $\mathrm{PmrD}$ on the PmrA

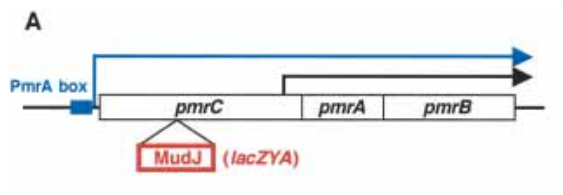

B

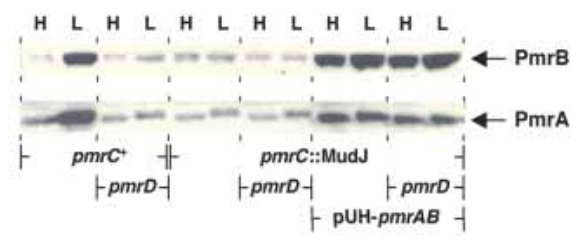

C

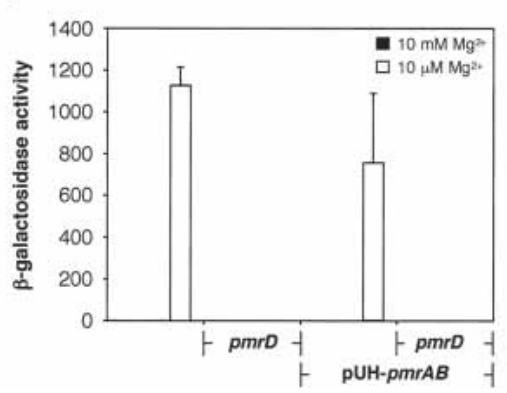

Figure 2. The PmrD protein activates the PmrA/PmrB system at a posttranslational level. (A) Genetic organization of the pmrCAB operon. The blue arrow indicates transcription from a promoter that is positively autoregulated by the PmrA/PmrB system; the black arrow denotes a constitutive promoter that produces basal levels of PmrA and PmrB proteins even under noninducing conditions. The red box indicates the location of the MudJ transposon insertion in strains EG9460 and EG11785. (B) Western blot analysis of extracts prepared from wild type (14028s), $p m r D$ (EG11491), pmrC::MudJ (EG9460), pmrC::MudJ pmrD (EG11785), pmrC::MudJ (EG9460) harboring $\mathrm{pUH}-\mathrm{pmr} A B$, and $\mathrm{pmr} C::$ MudJ $p m r D$ (EG11785) harboring pUH-pmrAB strains grown in N-minimal medium at $\mathrm{pH} 7.7$ with $10 \mathrm{mM} \mathrm{Mg}^{2+}(\mathrm{H})$ or $10 \mu \mathrm{M} \mathrm{Mg}^{2+}(\mathrm{L})$ detected with anti$\mathrm{PmrB}_{\mathrm{c}}$ (upper panel) or anti-PmrA (lower panel) antibodies. $(C)$ $\beta$-galactosidase activity (Miller units) from a pmrC-lac transcriptional fusion expressed by bacteria grown in $\mathrm{N}$-minimal medium at $\mathrm{pH} 7.7$ with $10 \mathrm{mM} \mathrm{Mg}^{2+}$ (solid bar) or $10 \mu \mathrm{M}$ $\mathrm{Mg}^{2+}$ (open bar) was determined in $\operatorname{pmrC}::$ MudJ (EG9460), pmrC::MudJ pmrD (EG11785), pmrC::MudJ (EG9460) harboring pUH-pmrAB, and $p m r C::$ MudJ $p m r D$ (EG11785) harboring pUH-pmrAB strains. The data correspond to mean values of three independent experiments performed in duplicate. Error bars correspond to the standard deviation (and are only shown if greater than the resolution of the figure). 
and/or PmrB proteins might be masked by PmrA/PmrB autogenous regulation.

To explore whether the PmrD protein affects the PmrA/PmrB system posttranslationally, we examined isogenic $p m r D$ strains expressing constant low levels of the PmrA and PmrB proteins (Fig. 2B) due to the presence of a MudJ transposon insertion within the $p m r C$ gene that blocks transcription from the PmrA-activated promoter upstream of the $p m r C$ gene but does not affect the constitutive $\operatorname{pmr} A B$ promoter (Fig. 2A). Although inactivation of the pmrD gene had no effect on the levels of PmrA and PmrB proteins produced by the $\operatorname{pmrC}:$ :MudJ strains (Fig. 2B), it abolished transcription of the PmrAactivated pmrC gene (Fig. 2C). Furthermore, even when the $\operatorname{pmrC}::$ MudJ strains produced constant high levels of PmrA and PmrB proteins due to the presence of a plasmid with the pmrAB genes under the control of the lac promoter (Fig. 2B), pmrC transcription was strictly dependent on the presence of a functional pmrD gene (Fig. 2C). These results indicate that the PmrD protein activates the PmrA/PmrB system at a posttranslational level.

\section{PmrD-dependent and -independent pathways use the same promoters to transcribe \\ PmrA-activated genes}

We mapped the transcription start sites for the PmrAactivated $\operatorname{pbg} P$ (Supplementary Fig. S1A) and $p m r C$ (Supplementary Fig. S1B) promoters in isogenic pmrD strains experiencing single activation signals (i.e., low $\mathrm{Mg}^{2+}$ and no $\mathrm{Fe}^{3+}$ or high $\mathrm{Mg}^{2+}$ and high $\left.\mathrm{Fe}^{3+}\right)$. S1 products of the same size were obtained with RNA from wild-type bacteria, indicating that the same promoters are used in both activation conditions. As expected, these products were absent from the $p m r D$ mutant when the inducing condition was low $\mathrm{Mg}^{2+}$, and from both wild-type and $\operatorname{pmrD}$ bacteria grown in high $\mathrm{Mg}^{2+}$ (Supplementary Fig. S1A,B), a condition that activates neither the PhoP/PhoQ nor the PmrA/PmrB systems (García Véscovi et al. 1996; Wösten et al. 2000). These results indicate that PmrD-promoted transcription of PmrA-activated genes does not involve a change in promoter specificity.

\section{The PmrD protein promotes phosphorylation} of the PmrA protein

We hypothesized that the PmrD protein might promote the phosphorylated state of the PmrA protein because PmrA binds to its target promoters with higher affinity when phosphorylated (Wösten and Groisman 1999), and because PmrD-mediated activation is abolished upon mutation of the putative site of PmrA phosphorylation (i.e., D51; Kox et al. 2000). After the PmrA protein was mixed with the phosphorylated cytoplasmic domain of the PmrB protein (i.e., phospho-PmrB ${ }_{c}$ ), rapid phosphotransfer to the PmrA protein was observed (Fig. 3A, lanes 1-6), in agreement with previous results (Wösten and Groisman 1999). The D51 residue is essential for PmrA phosphorylation because phosphotransfer from
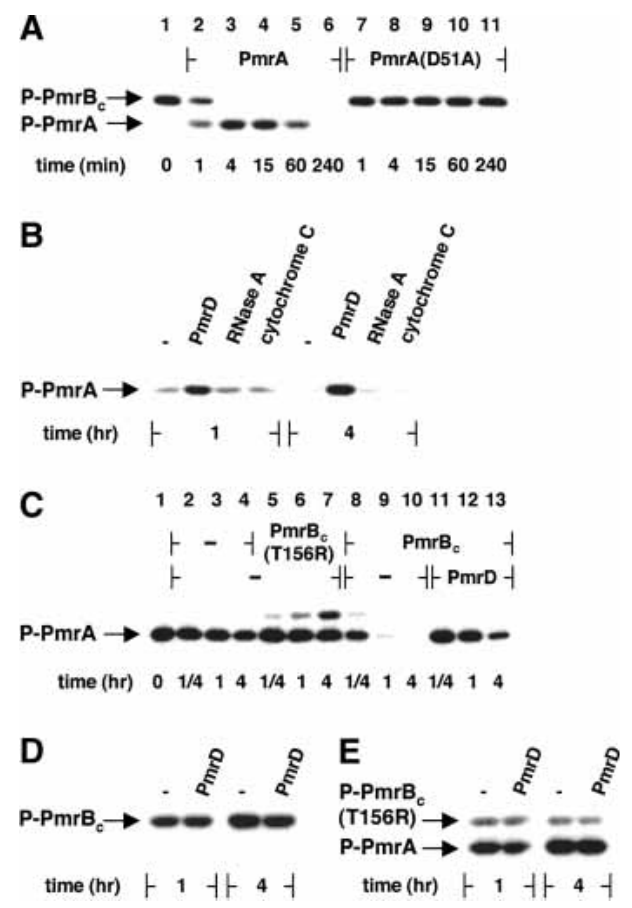

Figure 3. The PmrD protein specifically promotes the phosphorylated state of the PmrA protein by inhibiting dephosphorylation of phospho-PmrA catalyzed by the PmrB protein. (A) Phosphotransfer assay from phospho-PmrB $\mathrm{C}_{\mathrm{c}}$ to the PmrA and PmrAD51A proteins was performed with $5 \mu \mathrm{M}$ of regulator (PmrA and PmrAD51A) and $2.5 \mu \mathrm{M}$ of $\mathrm{PmrB}_{\mathrm{c}}$ proteins. (B) Kinase/phosphatase assay of the $\mathrm{PmrB}_{\mathrm{c}}$ and $\mathrm{PmrA}$ proteins was performed in the presence (PmrD) or absence (-) of the PmrD protein. The concentrations of the PmrA, $\mathrm{PmrB}_{\mathrm{c}}$ and $\mathrm{PmrD}$ proteins were $5,2.5$, and $5 \mu \mathrm{M}$, respectively. The small cationic proteins RNase $\mathrm{A}$ and cytochrome $\mathrm{C}$ were used as negative controls at a final concentration of $5 \mu \mathrm{M}$. $(C)$ Phosphatase assay of phospho-PmrA protein was performed as follows: ${ }^{32} \mathrm{P}$-labeled phosphorylated GST-PmrB ${ }_{\mathrm{c}}$ T156R beads were used as phosphodonor for the PmrA protein and removed before the phosphatase assay. The concentrations of the PmrA, histidine kinase (i.e., $\left.\mathrm{PmrB}_{\mathrm{c}}, \mathrm{PmrB}_{\mathrm{c}} \mathrm{T} 156 \mathrm{R}\right)$, and $\mathrm{PmrD}$ proteins were 2.5, 5, and 2.5 $\mu \mathrm{M}$, respectively. The top band corresponds to phospho$\mathrm{PmrB}_{\mathrm{c}}$ T156R or phospho-PmrB ${ }_{\mathrm{c}}$ due to reverse-phosphorylation from phospho-PmrA. (D) Autokinase assay of the $\mathrm{PmrB}_{\mathrm{c}}$ protein was performed in the presence $(\mathrm{PmrD})$ or absence $(-)$ of the PmrD protein. The concentrations of the $\mathrm{PmrB}_{\mathrm{c}}$ and $\mathrm{PmrD}$ proteins were 2.5 and $5 \mu \mathrm{M}$, respectively. $(E)$ Kinase/phosphatase assay of the $\mathrm{PmrB}_{\mathrm{c}} \mathrm{T} 156 \mathrm{R}$ and PmrA proteins was performed in the presence $(\mathrm{PmrD})$ or absence $(-)$ of the $\mathrm{PmrD}$ protein. The concentrations of the PmrA, $\mathrm{PmrB}_{\mathrm{c}} \mathrm{T} 156 \mathrm{R}$, and $\mathrm{PmrD}$ proteins were $5,2.5$, and $5 \mu \mathrm{M}$, respectively. Samples were analyzed by $10 \%$ SDS-PAGE.

phospho- $\mathrm{PmrB}_{\mathrm{c}}$ was abolished if the PmrA protein was replaced with the PmrAD51A protein (Fig. 3A, lanes 7-11). (We used the purified $\mathrm{PmrB}_{\mathrm{c}}$ protein in our experiments because bacteria expressing $\mathrm{PmrB}_{\mathrm{c}}$ recapitulate the PmrD-dependent activation of PmrA-regulated genes displayed by the full-length PmrB protein; Supplementary Fig. S2.)

The PmrD protein promoted higher levels of PmrA phosphorylation when incubated with PmrA, $\mathrm{PmrB}_{\mathrm{c}}$ 
and ATP (Fig. 3B). Two types of controls indicate that PmrD specifically acts on the PmrA/PmrB system: First, the small (85 amino acid) and basic (pI, 9.5) PmrD could not be replaced by other small basic proteins, such as RNase A and cytochrome C, to promote the phosphorylated state of the PmrA protein (Fig. 3B). And second, PmrD had no effect on the phosphorylation of YgiX and YgiY (data not shown), which are the two-component system proteins exhibiting the highest identity to the Salmonella PmrA and PmrB proteins, respectively. The PmrD protein affects phosphorylation but not stability of the PmrA protein, because the same levels of PmrA protein were present when incubations were carried out in the presence/absence of PmrD (data not shown). These results demonstrate that the PmrD protein promotes the phosphorylated state of the PmrA protein, and that protein components other than $\mathrm{PmrB}_{\mathrm{c}}$ are not required for the PmrD effect.

The PmrD protein inhibits PmrB-promoted dephosphorylation of phospho-PmrA

The PmrD protein may favor phosphorylation of the PmrA protein by promoting autokinase and/or PmrA phosphotransferase activities of $\mathrm{PmrB}_{\mathrm{c}}$ (Fig. 3A), and/or by inhibiting a putative phosphatase activity of $\mathrm{PmrB}_{\mathrm{c}}$ towards phospho-PmrA. To test the latter possibility, we first determined that the phosphoryl group in phospho-
PmrA was stable for at least $4 \mathrm{~h}$ in the absence of $\mathrm{PmrB}_{\mathrm{c}}$ (Fig. 3C, lanes 1-4), but that it was rapidly lost when $\mathrm{PmrB}_{\mathrm{c}}$ was present (Fig. 3C, lanes 8-10). Then, we established that the PmrD protein inhibited the $\mathrm{PmrB}_{\mathrm{c}}$-promoted dephosphorylation of phospho-PmrA (Fig. 3C, lanes 11-13). On the other hand, PmrD affected neither the ability of $\mathrm{PmrB}_{\mathrm{c}}$ to autophosphorylate from ATP (Fig. 3D) nor the levels of phospho-PmrA in incubations carried out with $\mathrm{PmrB}_{\mathrm{c}} \mathrm{T} 156 \mathrm{R}$ as phosphodonor (Fig. 3E), a mutant $\mathrm{PmrB}_{\mathrm{c}}$ lacking phospho-PmrA phosphatase activity (Fig. 3C, lanes 5-7) that enabled us to examine the phosphotransfer reaction. Cumulatively, these results establish that $\mathrm{PmrB}_{\mathrm{c}}$ has phospho-PmrA phosphatase activity and that PmrD can prevent the PmrB-promoted dephosphorylation of phospho-PmrA.

The PmrD protein binds to phospho-PmrA, inhibiting its dephosphorylation

The PmrD protein may inhibit dephosphorylation of phospho-PmrA by targeting $\mathrm{PmrB}_{\mathrm{c}}$ and/or by directly binding to phospho-PmrA, protecting it from $\mathrm{PmrB}_{\mathrm{c}}{ }^{\text {'s }}$ phosphatase activity. We established that the PmrD protein specifically immunoprecipitated phospho-PmrA, as it could not precipitate the phospho-YgiX response regulator or the phospho- $\mathrm{PmrB}_{\mathrm{c}}$ protein (Fig. 4A). PmrD appears to interact exclusively with the phosphorylated form of PmrA, because no precipitation was detected

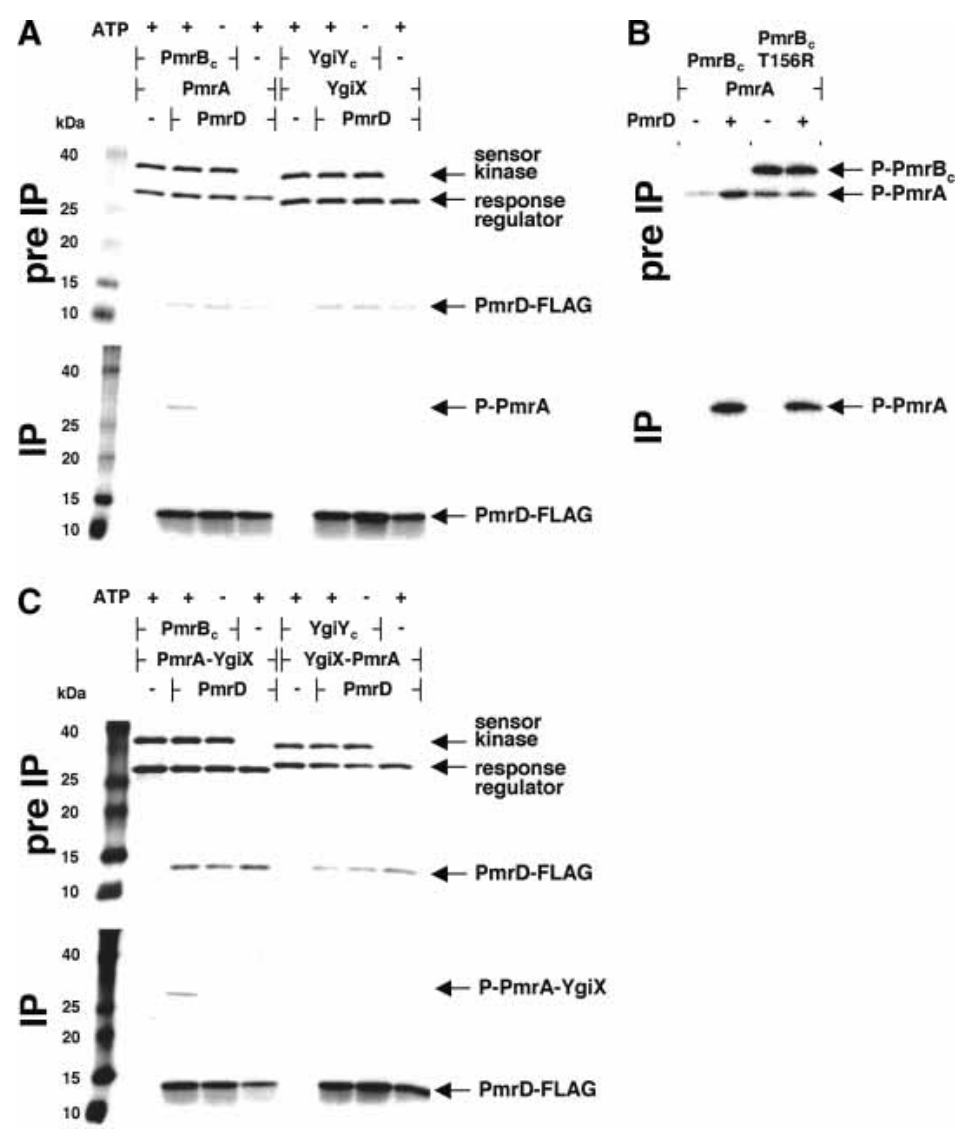

Figure 4. The PmrD protein interacts with the N-terminal domain of phospho-PmrA in a phosphorylationdependent manner. (A) Immunoprecipitation of PmrDFlag protein complexed with phospho-PmrA. Regulator (PmrA and $\mathrm{YgiX})$, sensor $\left(\mathrm{PmrB}_{\mathrm{c}}\right.$ and $\left.\mathrm{YgiY}_{\mathrm{c}}\right)$, and $\mathrm{PmrD}$ Flag proteins were incubated with ATP for $16 \mathrm{~h}$ before immunoprecipitation (pre-IP). The PmrD-Flag protein was precipitated from the phosphorylation reaction mixture using anti-Flag beads (IP). (B) Immunoprecipitation of the PmrD-Flag protein complexed with phospho-PmrA after phosphorylation with $\left[\gamma_{-}{ }^{32} \mathrm{P}\right]$ ATP. PmrA, sensor $\left(\mathrm{PmrB}_{\mathrm{c}}\right.$ and $\left.\mathrm{PmrB}_{\mathrm{c}} \mathrm{T} 156 \mathrm{R}\right)$, and PmrD-Flag proteins were incubated with $\left[\gamma^{-}{ }^{32} \mathrm{P}\right]$ ATP for $4 \mathrm{~h}$ before immunoprecipitation (pre-IP). PmrD-Flag protein was precipitated from the phosphorylation reaction mixture using anti-Flag beads (IP). Coimmunoprecipitated PmrA protein retains phosphoryl group. $(C)$ Immunoprecipitation of the PmrD-Flag protein complexed with phospho-PmrA-YgiX. Chimeric regulator (PmrA-YgiX and YgiX-PmrA), sensor ( $\mathrm{PmrB}_{\mathrm{c}}$ and $\left.\mathrm{YgiYc}\right)$, and PmrDFlag proteins were incubated with ATP for $16 \mathrm{~h}$ before immunoprecipitation (pre-IP). The PmrD-Flag protein was precipitated from the phosphorylation reaction mixture using anti-Flag beads (IP). 
when ATP or $\mathrm{PmrB}_{\mathrm{c}}$ was omitted from the reaction (Fig. 4A). This was confirmed by conducting PmrA phosphorylation with $\left[\gamma_{-}{ }^{32} \mathrm{P}\right]$ ATP using either $\mathrm{PmrB}_{\mathrm{c}}$ or the phosphatase-defective PmrBT156R $\mathrm{R}_{\mathrm{c}}$ and detecting the immunoprecipitated phospho-PmrA by autoradiography (Fig. 4B). These results demonstrate that the PmrD protein specifically binds to the phospho-PmrA protein.

Consistent with the notion that PmrD specifically targets phospho-PmrA, we determined that the PmrD protein inhibited the spontaneous dephosphorylation of phospho-PmrA (i.e., in the absence of $\mathrm{PmrB}_{\mathrm{c}}$; Fig. 5A) but had no effect on the dephosphorylation of phospho-YgiX (Fig. 5B). Because GST-PmrB T156R was used as phosphodonor for the PmrA protein in these experiments, it was possible that the PmrD protein was inhibiting a phospho-PmrA phosphatase activity mediated by trace amounts of GST-PmrB ${ }_{c}$ T156R protein /despite such putative activity being undetectable in our assays; Fig. 3C). To rule out this possibility, we repeated the experiment using PmrA protein that had been phosphorylated with the noncognate sensor GST-YgiY ${ }_{c}$ which does not exhibit phosphatase activity towards phospho-PmrA (data not shown). The PmrD protein still inhibited the spontaneous dephosphorylation of phos-
pho-PmrA under conditions in which there was no $\mathrm{PmrB}_{\mathrm{c}}$ protein and where none of the proteins used in the reaction had been in contact with PmrB (Fig. 5C). These experiments establish that the PmrD protein binds to the phospho-PmrA protein, inhibiting its dephosphorylation.

\section{The PmrD protein targets the N-terminal domain of phospho-PmrA}

To identify the domain of the PmrA protein targeted by PmrD, we investigated the ability of the PmrD protein to inhibit dephosphorylation of two chimeric proteins: one consisting of the $\mathrm{N}$-terminal response regulator domain of the PmrA protein fused to the C-terminal DNA-binding domain of the YgiX protein, and the other harboring the $\mathrm{N}$-terminal response regulator domain of the YgiX protein fused to the C-terminal DNA-binding domain of the PmrA protein. The PmrD protein inhibited dephosphorylation of the chimera harboring the N-terminal domain of the PmrA protein, but had no effect on the dephosphorylation of the chimera harboring the N-terminal domain of the YgiX protein, regardless of the presence of sensor proteins (i.e., $\mathrm{PmrB}_{\mathrm{c}}$ or $\mathrm{YgiY}_{\mathrm{c}}$ ) in the

Figure 5. The PmrD protein specifically inhibits dephosphorylation of phospho-PmrA by targeting its N-terminal region. (A) Spontaneous dephosphorylation of phospho-PmrA protein in the presence $(\mathrm{PmrD})$ or absence $(-)$ of the $\mathrm{PmrD}$ protein: ${ }^{32}$ P-labeled phosphorylated GST-PmrB $156 \mathrm{R}$ beads were used as phosphodonor for the PmrA protein and removed before the assay. The concentrations of the PmrA and PmrD proteins were $2.5 \mu \mathrm{M}$. (B) Spontaneous dephosphorylation of phosphoYgiX protein was performed in the presence (PmrD) or absence (-) of the PmrD protein. ${ }^{32}$ P-labeled phosphorylated GST-YgiY ${ }_{c}$ beads were incubated with the YgiX protein for $1 \mathrm{~h}$ to produce phosphoYgiX protein and removed before the assay. The concentrations of the $\mathrm{YgiX}$ and $\mathrm{PmrD}$ proteins were $2.5 \mu \mathrm{M} .(C)$ Spontaneous dephosphorylation of phospho-PmrA protein was performed in the presence (PmrD) or absence (-) of PmrD protein. All proteins used in this assay were not in contact with PmrB or derivatives, because they were independently overexpressed in E. coli strain EG13796, which lacks the entire pmrAB homolog basRS, and purified as described in Materials and Methods. ${ }^{32} \mathrm{P}$-labeled phosphorylated GST-YgiY $\mathrm{C}_{\mathrm{c}}$ beads were

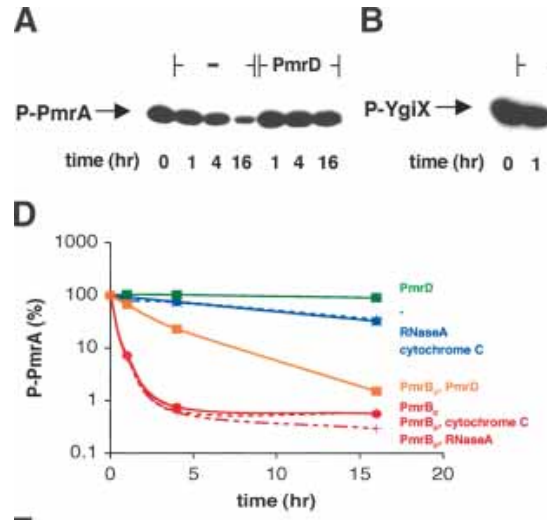

F

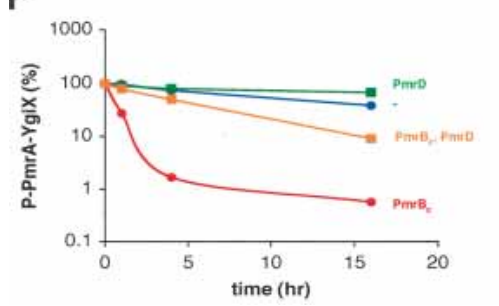

$\vdash-H P \operatorname{Pmo} t$

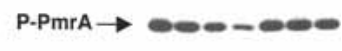

time (hr) $0 \begin{array}{lllllllllll} & 1 & 4 & 16 & 1 & 4 & 16\end{array}$

E

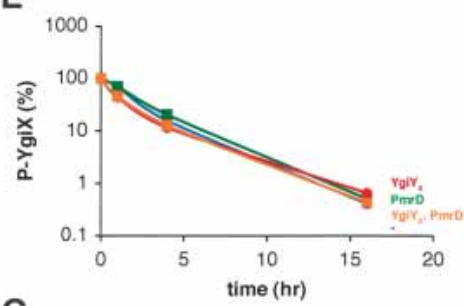

G

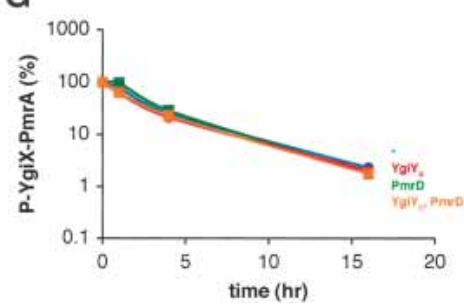
used as phosphodonor for the PmrA protein and removed before the assay. The concentration of the PmrA and PmrD proteins was 2.5 $\mu \mathrm{M}$. (D) Quantitative analysis of the phosphatase assay of phospho-PmrA protein. ${ }^{32} \mathrm{P}$-labeled phosphorylated GST-YgiY $\mathrm{C}_{\mathrm{c}}$ beads were used as phosphodonor for the PmrA protein and removed before the assay. The concentrations of the PmrA, PmrB ${ }_{c}$, and PmrD proteins were 2.5, 5, and $2.5 \mu \mathrm{M}$, respectively. The small cationic proteins RNase A and cytochrome $\mathrm{C}$ were used as negative controls at a final concentration of $2.5 \mu \mathrm{M}$. (E) Quantitative analysis of the phosphatase assay of phospho-YgiX protein. ${ }^{32} \mathrm{P}$-labeled phosphorylated GST-PmrB ${ }_{\mathrm{c}}$ T156R beads were incubated with the YgiX protein for $45 \mathrm{~min}$ to produce phospho-YgiX protein and removed before the assay. The concentrations of $\mathrm{YgiX}_{\text {, }} \mathrm{YgiY}_{\mathrm{c}}$, and $\mathrm{PmrD}$ proteins were 2.5, 5, and $2.5 \mu \mathrm{M}$, respectively. (F) Quantitative analysis of the phosphatase assay of phospho-PmrA-YgiX protein. ${ }^{32} \mathrm{P}$-labeled phosphorylated GST-YgiY beads were incubated with the PmrA-YgiX protein for $2 \mathrm{~h}$ to produce phospho-PmrA-YgiX protein and removed before the assay. The concentrations of the PmrA-YgiX, PmrB ${ }_{\mathrm{c}}$ and PmrD proteins were 2.5, 5, and $2.5 \mu \mathrm{M}$, respectively. $(G)$ Quantitative analysis of the phosphatase assay of phospho-YgiX-PmrA protein. ${ }^{32} \mathrm{P}$-labeled phosphorylated GST-PmrB ${ }_{\mathrm{c}}$ T156R beads were incubated with the YgiX-PmrA protein for $2 \mathrm{~h}$ to produce phosphoYgiX-PmrA protein and removed before the assay. The concentrations of the YgiX-PmrA, YgiY ${ }_{c}$, and PmrD proteins were 2.5, 5 and $2.5 \mu \mathrm{M}$, respectively. Samples were analyzed by 10\% SDS-PAGE and quantified as described in Materials and Methods. 
reaction (Fig. 5D-G). In agreement with these results, the PmrD protein immunoprecipitated phospho-PmrAYgiX but not phospho-YgiX-PmrA (Fig. 4C). Cumulatively, these findings demonstrate that PmrD prevents dephosphorylation of phospho-PmrA by targeting its Nterminal region, which harbors the putative phosphorylation site (D51) that is required for PmrD-mediated activation of the PmrA protein in vivo (Kox et al. 2000) and for phosphotransfer from phospho- $\mathrm{PmrB}_{\mathrm{c}}$ in vitro (Fig. 3A).

\section{A model for PmrD action}

The biochemical experiments described above suggest the following model for the PmrD-mediated activation of the PmrA/PmrB system: The PmrB protein continuously autophosphorylates from ATP and transfers the phosphoryl group to the PmrA protein (Fig. 3A). However, in the absence of its specific signal (i.e., $\mathrm{Fe}^{3+}$ ), the PmrB protein dephosphorylates phospho-PmrA. The low $\mathrm{Mg}^{2+}$ signal activates the PhoP/PhoQ system /García Véscovi et al. 1996), which promotes expression of the PmrD protein (Kox et al. 2000), which, in turn, binds phospho-PmrA (Fig. 4A,B) by targeting its N-terminal domain (Figs. 4C, 5D-G) and protects it from PmrB-promoted dephosphorylation (Figs. 3C, 5D,F). This promotes binding of phospho-PmrA to its target promoters to regulate gene transcription (Wösten and Groisman 1999). The model predicts that expression of PmrA-activated genes should still occur in the absence of the PmrD protein in strains with either a defective PmrB protein lacking phosphatase activity or harboring a mutant PmrA that is resistant to PmrB-promoted dephosphorylation. Below, we describe genetic experiments that test these predictions.

\section{A PmrB protein defective in phospho-PmrA phosphatase activity allows transcription of PmrA-activated genes independently of the PmrD protein}

Because $\mathrm{PmrB}_{\mathrm{c}}$ catalyzes the dephosphorylation of phospho-PmrA (Figs. 3C, 5D), it is likely that PmrD binding to phospho-PmrA is designed to prevent PmrB from dephosphorylating phospho-PmrA in vivo. Thus, we examined transcription of the PmrA-activated $p m r C$ gene in isogenic pmrD strains deleted for the $p m r B$ gene and harboring a plasmid expressing either wild-type PmrB or the mutant PmrBT156R, which, in vitro, lacks phosphoPmrA phosphatase activity (Fig. 3C). Consistent with our previous results (Kox et al. 2000), transcription of the $p m r C$ gene was $p m r D$-dependent when the bacteria expressing the wild-type $\mathrm{PmrB}$ protein were grown in low $\mathrm{Mg}^{2+}$ but $p m r D$-independent when the inducing condition was $\mathrm{Fe}^{3+}$ (Fig. 6A,B). In contrast, transcription of the $p m r C$ gene was $p m r D$-independent under all conditions in bacteria expressing the phosphatase-defective PmrBT156R protein (Fig. 6A,B). As expected, there was no $p m r C$ expression when bacteria expressing wild-type PmrB were grown in the absence of inducing signals (i.e.,
A

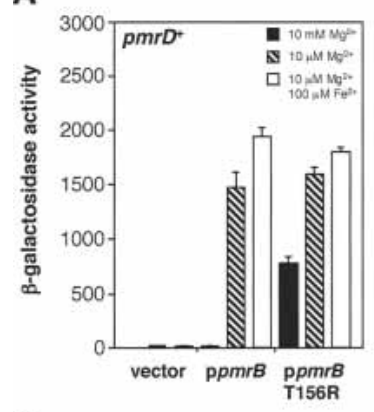

C

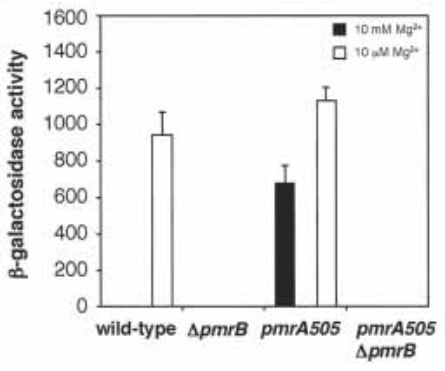

B

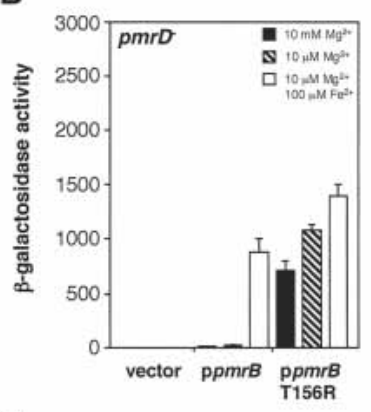

D

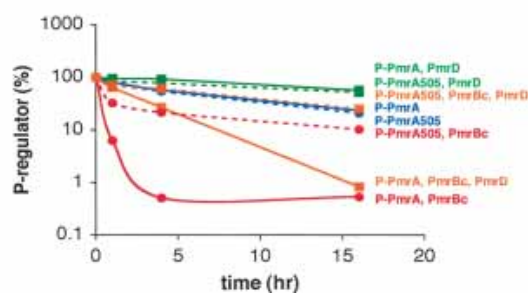

Figure 6. Transcription of PmrA-activated genes is rendered $p m r D$-independent upon inactivation of the phosphatase activity of the PmrB protein or in a PmrA mutant protein resistant to $\mathrm{PmrB}_{\mathrm{c}}{ }^{\prime}$ s phosphatase activity. (A) $\beta$-galactosidase activity (Miller units) from a pmrC-lac transcriptional fusion expressed by bacteria grown in $\mathrm{N}$-minimal medium at pH 7.7 with $10 \mathrm{mM} \mathrm{Mg}^{2+}$ (solid bars), $10 \mu \mathrm{M} \mathrm{Mg}^{2+}$ (hatched bars), or $10 \mu \mathrm{M} \mathrm{Mg}^{2+}$ and $100 \mu \mathrm{M} \mathrm{Fe}^{2+}$ (open bars) was determined in a $p m r B$ strain (EG14087) harboring pCCR9 (vector), pCCR9-pmrB (ppmrB), or pCCR9-pmrBT156R2 (ppmrBT156R). (B) $\beta$-galactosidase activity (Miller units) from a pmrC-lac transcriptional fusion expressed by bacteria grown in $\mathrm{N}$ minimal medium at $\mathrm{pH} 7.7$ with $10 \mathrm{mM} \mathrm{Mg}^{2+}$ (solid bars), $10 \mu \mathrm{M} \mathrm{Mg}^{2+}$ (hatched bars), or $10 \mu \mathrm{M} \mathrm{Mg}^{2+}$ and $100 \mu \mathrm{M} \mathrm{Fe}^{2+}$ (opened bars) was determined in the pmrB pmrD strain EG14090 harboring pCCR9 (vector), pCCR9-pmrB (ppmrB), or pCCR9-pmrBT156R2 (ppmrBT156R). (C) $\beta$-galactosidase activity (Miller units) from a pbgP-lac transcriptional fusion expressed by bacteria grown in $\mathrm{N}$-minimal medium at pH 7.7 with $10 \mathrm{mM} \mathrm{Mg}^{2+}$ (solid bars) or $10 \mu \mathrm{M} \mathrm{Mg}^{2+}$ (opened bars) was determined in wild-type (EG9888), pmrB (EG13735), pmrA505 (EG9868), or pmrA505 and $\operatorname{pmrB}$ (EG13641) strains. The data correspond to mean values of three independent experiments performed in duplicate. Error bars show standar deviation (and are only shown if greater than the resolution of the figure). $(D)$ Quantitative analysis in the phosphatase assay of phospho-PmrA and phospho-PmrA505 proteins was performed as follows: ${ }^{32}$ P-labeled phosphorylated GST-PmrB ${ }_{\mathrm{c}}$ T156R beads were used as phosphodonor for the PmrA and PmrA505 proteins and removed before the assay. The concentrations of the PmrA, PmrA505, PmrB ${ }_{c}$, and PmrD proteins were 2.5, 2.5, 5, and $2.5 \mu \mathrm{M}$, respectively. Samples were analyzed by 10\% SDS-PAGE. 
high $\mathrm{Mg}^{2+}$ and no $\mathrm{Fe}^{3+}$ ) or in strains harboring the plasmid vector. These results support the notion that PmrD is required to antagonize PmrB-promoted dephosphorylation of phospho-PmrA.

\section{A PmrD-independent allele of the PmrA protein is resistant to PmrB-promoted dephosphorylation}

Salmonella strains with the PmrA505 protein (Roland et al. 1993) transcribe PmrA-activated genes even in a pmrD mutant and under repressing $\mathrm{Mg}^{2+}$ concentrations (Kox et al. 2000). This could be due to the PmrA505 protein adopting a conformation that mimics phosphoPmrA and thus no longer requiring phosphorylation for activation. Alternatively, the PmrA505 protein, which has the $\mathrm{R} 81 \mathrm{H}$ substitution in the $\mathrm{N}$-terminal response regulator domain, may depend on phosphorylation to activate transcription, but it may be resistant to PmrBpromoted dephosphorylation. To distinguish between these two possibilities, we examined transcription of the PmrA-activated $p b g P$ gene in isogenic $p m r B$ strains that expressed either wild-type PmrA or PmrA505 proteins. Transcription of the $p b g P$ gene was dependent on a functional pmrB gene in the pmrA505 strain as it is in a pmr $A^{+}$strain (Fig. 6C). These results indicate that the pmrA505 allele is not truly constitutive because it requires the PmrB protein to promote $p b g P$ transcription in vivo.

To investigate whether the PmrA505 protein is resistant to PmrB-promoted dephosphorylation, we purified this mutant protein, phosphorylated it with GST$\mathrm{PmrB}_{\mathrm{c}}$ T156R, and incubated it in the presence of $\mathrm{PmrB}_{\mathrm{c}}$. The phospho-PmrA505 protein displayed resistance to $\mathrm{PmrB}_{\mathrm{c}}$-promoted dephosphorylation (Fig. 6D), although its intrinsic dephosphorylation was similar to that of phospho-PmrA (Fig. 6D). Moreover, PmrD could still inhibit the dephosphorylation of phospho-PmrA505 (Fig. 6D). These results imply that the pmrA505 strain expresses PmrA-activated genes under noninducing conditions (i.e., high $\mathrm{Mg}^{2+}$ and no $\mathrm{Fe}^{3+}$ ) because it can resist PmrB's phosphatase activity.

\section{Discussion}

We have uncovered the mechanism by which the PmrA/ PmrB two-component system can respond to the low $\mathrm{Mg}^{2+}$ signal controlling the PhoP/PhoQ two-component system. We established that the PhoP-activated PmrD protein promotes the phosphorylated state of the response regulator PmrA by binding phospho-PmrA at the $\mathrm{N}$-terminal domain, which inhibits both its intrinsic dephosphorylation and that catalyzed by its cognate sensor PmrB. Because phospho-PmrA binds to its target promoters with higher affinity than unphosphorylated PmrA (Wösten and Groisman 1999), transcription of PmrA-activated genes is promoted in the presence of PmrD.

The PmrB protein appears to phosphorylate the PmrA protein independently of the absence/presence of signals, because even when the ability of the PmrB protein to dephosphorylate phospho-PmrA is blocked, either by the T156R mutation in PmrB or the $\mathrm{R} 81 \mathrm{H}$ mutation in PmrA, significant transcription of the PmrA-activated genes is observed in high $\mathrm{Mg}^{2+}$ (Fig. 6A,C). This PmrB activity is responsible for generating phospho-PmrA, which constitutes the target of the PmrD protein (Fig. 4), and explains the requirement for the PmrB protein in the PmrD-mediated activation of the PmrA protein that takes place in low $\mathrm{Mg}^{2+}$ (Fig. 6C; Kox et al. 2000). Moreover, by interacting with phospho-PmrA (and not with unphosphorylated PmrA), the PmrD protein specifically inhibits the dephosphorylation of phospho-PmrA catalyzed by PmrB without affecting the phosphotransfer reaction from phospho-PmrB to PmrA.

The PmrD-mediated protection of a phosphorylated response regulator from dephosphorylation by its cognate sensor kinase constitutes a unique regulatory strategy in two-component signal transduction. By targeting phospho-PmrA, the PmrD protein expands the environments where PmrA-activated genes (including those mediating resistance to polymyxin B) are expressed without interfering with PmrB's autokinase activity (Fig. 3D) or PmrB's phosphotransferase activity to PmrA (Fig. 3E). This is in contrast to previously described activities affecting two-component system proteins. For example, the decision of Bacillus subtilis to sporulate is modulated by two families of phosphatases (i.e., Rap and SpoOE) acting on the response regulators SpoOF and Spo0A (Perego et al. 1994; Perego and Hoch 1996; Perego 1998 ) and by inhibitors of the sensor kinase KinA (i.e., KipI and Sda; Wang et al. 1997; Burkholder et al. 2001; Rowland et al. 2004), which altogether provide multiple checkpoints for the sporulation phosphorelay. Likewise, when Escherichia coli experiences high cytoplasmic levels of glutamine, the PII protein interacts with the histidine kinase NRII, which decreases NRII's autokinase activity and promotes its phosphatase activity towards its cognate regulator NRI. This results in lower levels of phospho-NRI and leads to reduced transcription of the glutamine synthetase $g \ln A$ gene (Atkinson et al. 1994; Jiang et al. 1998; Jiang and Ninfa 1999; Pioszak et al. 2000). Thus, in contrast to the Rap, Spo0E, KipI, Sda, and PII proteins, which integrate signals by functioning as Boolean NOT operators, the PmrD protein expands the conditions in which a two-component system operates by functioning as an OR operator (Bijlsma and Groisman 2003).

The protective activity of the PmrD protein is reminiscent of that displayed by certain members of the 143-3 protein family in eukaryotes in that both modify cellular behavior by protecting the phosphorylated state of certain proteins (Tzivion and Avruch 2002). However, whereas 14-3-3 proteins recognize particular phosphoserine- and phosphothreonine-containing domains (Yaffe et al. 1997; Obsil et al. 2001; Yaffe and Smerdon 2001), the PmrD protein specifically targets the N-terminal domain of PmrA, which harbors the aspartate residue (D51) that is the predicted site of phosphorylation (Fig. 3A). Basic residues in the high-pI PmrD protein may participate in the recognition of the phosphoaspartate in PmrA 
as observed for the interaction between 14-3-3 proteins and their phosphorylated targets (Yaffe et al. 1997; Obsil et al. 2001; Yaffe and Smerdon 2001). Alternatively, phosphorylation of the PmrA protein may promote a conformational change that facilitates PmrA binding to the PmrD protein.

Regulatory networks, pathways, and proteins themselves are frequently constructed in a cassette-like fashion using domains that mediate molecular interactions or have distinct enzymatic activities (Pawson and Nash 2003). Signal transduction in eukaryotes usually involves kinases phosphorylating tyrosine, serine, or threonine residues, which are recognized in certain amino acid contexts by interaction modules such as $\mathrm{SH} 2, \mathrm{PTB}, \mathrm{FHA}, \mathrm{WW}$ domains and 14-3-3 proteins that have been used repeatedly to regulate different aspects of cellular organization (Yaffe and Smerdon 2001; Pawson and Nash 2003). Two-component signal transduction, which is present in all domains of life and is the dominant form that bacteria use to respond to environmental stress, relies on sensor kinases that autophosphorylate on a histidine residue and modify the activity of regulatory proteins by phosphorylation of an aspartate residue. The activity of the PmrD protein uncovered in this study demonstrates that bacteria have the means of interconnecting signal transduction pathways in a phosphorylation-dependent manner.

\section{Materials and methods}

\section{Bacterial strains, plasmids, and growth conditions}

Bacterial strains and plasmids used in this study are listed in Table 1. Salmonella enterica serovar Typhimurium strains are derived from wild-type strain 14028s. Phage P22-mediated transductions were performed as described (Davis et al. 1980). Bacteria were grown at $37^{\circ} \mathrm{C}$ in Luria-Bertani broth (LB; Sambrook et al. 1989) or in N-minimal medium at pH 7.7 (Snavely et al. 1991) supplemented with $0.1 \%$ Casamino Acids, $38 \mathrm{mM}$ glycerol, $10 \mu \mathrm{M}$ or $10 \mathrm{mM} \mathrm{MgCl}_{2}$, and $100 \mu \mathrm{M} \mathrm{FeSO}_{4}$ or $100 \mu \mathrm{M}$ $\mathrm{FeCl}_{3}$. Ampicillin and kanamycin were used at $50 \mu \mathrm{g} / \mathrm{mL}$, tetracycline at $12.5 \mu \mathrm{g} / \mathrm{mL}$, and chloramphenicol at $20 \mu \mathrm{g} / \mathrm{mL}$.

\section{Plasmid constructions}

Plasmid pTYB11-PmrD-Flag encoding the PmrD protein fused to a self-cleavable Intein tag at the $\mathrm{N}$ terminus and a Flag epitope tag at the $\mathrm{C}$ terminus was constructed by cloning between the SapI and PstI sites of plasmid pTYB11 (New England Biolabs) a PCR fragment containing the $\operatorname{pmrD}$ coding region and a Flag epitope tag generated with primers $1706\left(5^{\prime}\right.$-GGTGGTT GCTCTTCCAACATGGAATGGTTGGTTA-3') and 1752 (5'AACTGCAGTCACTTGTCATCGTCGTCCTTGTAGTCTG ATGGCTTGCGCGTCAAC-3') and pLK4 as template, and digested with SapI and PstI.

Plasmid pUH-ygiXY, containing the coding regions of the YgiX and YgiY proteins, was constructed by cloning between the BamHI and SalI sites of plasmid pUHE21-21acI ${ }^{q}$ a PCR fragment generated with primers $1575\left(5^{\prime}\right.$-GAGGATCCGATGC GAATTTTACTG-3') and 1606 (5'-AAGCTCGAGTTACCAA CTTACTACG-3') and 14028s genomic DNA as template, and digested with BamHI and XhoI.
Plasmid pCCR9-pmrBT156R2 was constructed by cloning between the BamHI and HindIII sites of plasmid pCCR9 a 1.8-kb BamHI-HindIII fragment containing the pmrBT156R coding region derived from plasmid pCCR9-pmrBT156R (Kato et al. 2003).

Plasmid pT7-7-PmrAD51A-His6 is a pT7-7-PmrA-His6 derivative (Wösten and Groisman 1999) that encodes a mutant PmrA protein harboring the D51A substitution in the putative phosphorylation site of the PmrA protein. The plasmid encoding this mutant PmrA protein was constructed as follows: A PCR fragment was amplified using primers 2453 (5'-GAGGA TCCATATGAAGATACTGATTG-3') and 2545 (5'-GGGCAG CCCTAACGCCAGCACCATCAG-3') and pUH-pmrAB (Soncini and Groisman 1996) as template. Another PCR fragment was amplified using primers 1121 (5'-CTGATGGTGCTGGC GTTAGGGCTGCCC-3') and 2454 (5'-TCCAAGCTTAGTGG TGGTGGTGGTGGTGGCTTTCCTCAGTGGCAACC-3') and pUH-pmr $A B$ as template. After digestion with DpnI to eliminate the original pUH-pmrAB DNA, these two fragments were annealed to each other and amplified using primers 2453 and 2454. The resulting PCR fragment was digested with NdeI and HindIII and ligated to pT7-7 plasmid DNA that had been digested with NdeI and HindIII.

Plasmid pT7-7-PmrA505-His6 is a pT7-7-PmrA-His6 derivative (Wösten and Groisman 1999) that harbors the pmrA505 allele, which encodes a PmrA protein with the R81H substitution that confers high levels of expression of PmrA-activated genes in LB (Roland et al. 1993) and in N-minimal medium at pH 7.7 with $10 \mathrm{mM} \mathrm{Mg}^{2+}$ (Kox et al. 2000) conditions. It was constructed by cloning between the NdeI and HindIII sites of pT7-7 a PCR fragment containing the pmrA505 coding region amplified using primers 2453 and 2454 and EG9492 (Groisman et al. 1997) genomic DNA as template, and digested with NdeI and HindIII.

Plasmid pT7-7-YgiX-His6 encodes a YgiX protein with His6 tag at the $\mathrm{C}$-terminal end. It was constructed by cloning between the NdeI and Sall sites of pT7-7 plasmid a PCR fragment generated with primers 2395 (5'-GAGGATCCATATGCGAA TTTTACTGGTAGAAGATG-3') and 2432 (5'-GCGCTCGAG TCAGTGGTGGTGGTGGTGGTGTGCGTCACCCAGGGTG TA-3') and pUH-ygiXY as template, and digested with NdeI and XhoI.

Plasmid pT7-7-AX-His6 encodes a chimeric protein whose $\mathrm{N}$-terminal receiver domain and C-terminal DNA-binding domain are derived from the PmrA and YgiX proteins, respectively. This protein also harbors a C-terminal His6 tag. The plasmid encoding this chimera was constructed as follows: A PCR fragment was amplified using primers 2453 and 2340 (5' GCGCAATTCGCTACTGGCCTGGTTATTATGGCGGCGC AGC-3') and pUH-pmrAB (Soncini and Groisman 1996) as template. Another PCR fragment was amplified using primers 2339 (5' -CTGCGCCGCCATAATAACCAGGCCAGTAGCGAATT GCGCC-3') and 2432 and pUH-ygiXY as template. After digestion with DpnI to eliminate the original plasmid DNAs, both fragments were annealed to each other and amplified using primers 2453 and 2432. The resulting PCR fragment was digested with NdeI and XhoI and ligated to pT7-7 plasmid DNA that had been digested with NdeI and SalI.

Plasmid pT7-7-XA-His6 encodes a chimeric protein whose $\mathrm{N}$-terminal receiver domain and $\mathrm{C}$-terminal DNA-binding domain are derived from the YgiX and PmrA proteins, respectively. This protein also harbors a C-terminal His6 tag. The plasmid encoding this chimera was constructed in a manner analogous to that used to make plasmid pT7-7-AX-His6 using primers 2454 , 2341 (5'-GGTACGCCGCGCCAGCGGTCAGG GTGAAAGTGAACTGACG-3'), 2342 (5'-CGTCAGTTCACT 
Table 1. Bacterial strains and plasmids used

\begin{tabular}{|c|c|c|}
\hline Strain or plasmid & Description & Reference or source \\
\hline \multicolumn{3}{|c|}{ S. enterica serovar Typhimurium } \\
\hline $14028 s$ & Wild type & Fields et al. 1986 \\
\hline EG10056 & $\Delta p m r B:: \mathrm{Cm}^{\mathrm{R}}$ & Kox et al. 2000 \\
\hline EG11491 & $p m r D:: \mathrm{Cm}^{\mathrm{R}}$ & Kox et al. 2000 \\
\hline EG10065 & $\operatorname{pbg} P 1::$ MudJ $\triangle p m r B:: \mathrm{Cm}^{\mathrm{R}}$ & Kox et al. 2000 \\
\hline EG12060 & pbgP1::MudJ pmrD $:: \mathrm{Cm}^{\mathrm{R}} \Delta p m r B:: \mathrm{Cm}^{\mathrm{R}}$ & Kox et al. 2000 \\
\hline EG9492 & pmrA505 zjd::Tn10d-Cam & Groisman et al. 1997 \\
\hline EG9888 & pbgP1::MudJ zjd::Tn10d-Cam & Groisman et al. 1997 \\
\hline EG13732 & $\Delta p m r B:: \mathrm{Km}^{\mathrm{R}}$ & This work \\
\hline EG13733 & $\Delta p m r B:: \mathrm{Km}^{\mathrm{R}}$ zjd::Tn10d-Cam & This work \\
\hline EG13734 & $\Delta p m r B$ zjd::Tn10d-Cam & This work \\
\hline EG13735 & pbgP1::MudJ $\triangle p m r B$ zjd::Tn10d-Cam & This work \\
\hline EG9868 & pbgP1::MudJ pmrA505 zjd::Tn10d-Cam & Groisman et al. 1997 \\
\hline EG13831 & pmrA505 spmrB zjd::Tn10d-Cam & This work \\
\hline EG13641 & pbgP1:: MudJ pmrA505 $\Delta$ pmrB zjd::Tn10d-Cam & This work \\
\hline EG9460 & pmrC ::MudJ & Kox et al. 2000 \\
\hline EG11785 & $p m r C::$ MudJ $p m r D:: \mathrm{Cm}^{\mathrm{R}}$ & Kox et al. 2000 \\
\hline EG14087 & $p m r C::$ MudJ $\Delta p m r B:: \mathrm{Cm}^{\mathrm{R}}$ & This work \\
\hline EG14089 & $\Delta p m r D$ & This work \\
\hline EG14090 & $p m r C::$ MudJ $\Delta p m r B:: \mathrm{Cm}^{\mathrm{R}} \Delta p m r D$ & This work \\
\hline \multicolumn{3}{|c|}{ F } \\
\hline DH5 $\alpha$ & $\begin{array}{l}\mathrm{F}^{-} \text {supE44 } \Delta \text { lacU169 (\$80 lacZDM15) hsdR17 recA1 endA1 gyrA96 } \\
\text { thi-1 relA1 }\end{array}$ & Hanahan 1983 \\
\hline ER2566 & 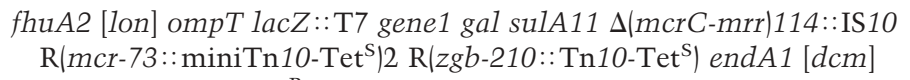 & New England Biolabs \\
\hline EG13796 & ER2566 $\Delta$ basRS:: $\mathrm{Cm}^{\mathrm{R}}$ & This work \\
\hline \multicolumn{3}{|l|}{ Plasmid } \\
\hline pKD3 & $\operatorname{rep}_{\mathrm{R} 6 \mathrm{~K} \gamma} \mathrm{Ap}^{\mathrm{R}} \mathrm{FRT} \mathrm{Cm}^{\mathrm{R}} \mathrm{FRT}$ & Datsenko and Wanner 2000 \\
\hline pKD46 & rep $_{\mathrm{pSC} 101}$ ts $\mathrm{Ap}^{\mathrm{R}} \mathrm{P}_{\text {araBAD }} \gamma \beta$ exo & Datsenko and Wanner 2000 \\
\hline pCP20 & rep $_{\mathrm{psC101}}$ ts $\mathrm{Ap}^{\mathrm{R}} \mathrm{Cm}^{\mathrm{R}} c I 857 \lambda \mathrm{P}_{\mathrm{R}} f l p$ & $\begin{array}{l}\text { Cherepanov and Wackernagel } \\
1995\end{array}$ \\
\hline pUHE21-2locI ${ }^{q}$ & $\operatorname{rep}_{\mathrm{pMB} 1} \mathrm{Ap}^{\mathrm{R}} l a c I^{q}$ & Soncini et al. 1995 \\
\hline pUH-pmrAB & $\operatorname{rep}_{\mathrm{pMB} 1} \mathrm{Ap}^{\mathrm{R}} 1 a c I^{q}$ pmrAB (pEG9102) & Soncini and Groisman 1996 \\
\hline pUH-pmrB & $\operatorname{rep}_{\mathrm{pMB} 1} \mathrm{Ap}^{\mathrm{R}} \operatorname{lacI}^{\mathrm{q}} \mathrm{pmrB}$ & Wösten et al. 2000 \\
\hline pUH-pmrB $B_{c}$ & $\operatorname{rep}_{\mathrm{pMB} 1} \mathrm{Ap}^{\mathrm{R}} 1 a c I^{q} \mathrm{pmr}_{c}$ & Wösten et al. 2000 \\
\hline pLK39 & $\operatorname{rep}_{\mathrm{pMB} 1} \mathrm{Ap}^{\mathrm{R}} 1 a c I^{q} p m r A(\mathrm{D} 51 \mathrm{~A}) B$ & Kox et al. 2000 \\
\hline pUH-ygiXY & $\operatorname{rep}_{\mathrm{pMB} 1} \mathrm{AP}^{\mathrm{R}} \operatorname{lacI}^{q}$ ygiXY & This work \\
\hline pLK4 & $\operatorname{rep}_{\mathrm{pMB} 1} \mathrm{Ap}^{\mathrm{R}} p b g P / E p m r D$ & Kox et al. 2000 \\
\hline pCCR9 & $\operatorname{rep}_{\mathrm{pSC101}} \mathrm{Tc}^{\mathrm{R}}$ & Randegger et al. 2000 \\
\hline pCCR9-pmrB & $\operatorname{rep}_{\mathrm{psc} 101} \mathrm{Tc}^{\mathrm{R}} p m r B$ & Kato et al. 2003 \\
\hline pCCR9-pmrBT156R & rep $_{\mathrm{psc101}} \mathrm{Tc}^{\mathrm{R}}$ pmrBT156R & Kato et al. 2003 \\
\hline pCCR9-pmrBT156R2 & rep psc101 $\mathrm{Tc}^{\mathrm{R}}$ pmrBT156R & This work \\
\hline pTYB11 & rep $_{\mathrm{pMB} 1} \mathrm{Ap}^{\mathrm{R}}$ lacI $^{q} \mathrm{~T} 7$ Intein & New England Biolabs \\
\hline pTYB11-PmrD-Flag & $\operatorname{rep}_{\mathrm{pMB} 1} \mathrm{Ap}^{\mathrm{R}} 1 a c I^{q} \mathrm{~T} 7$ Intein-pmrD-Flag & This work \\
\hline pT7-7 & rep $_{\mathrm{PMB} 1} \mathrm{Ap}^{\mathrm{R}} \mathrm{p}_{\mathrm{T} 7}$ & Tabor and Richardson 1985 \\
\hline pT7-7-PmrA-His6 & rep $_{\mathrm{pMB} 1} \mathrm{Ap}^{\mathrm{R}} \mathrm{p}_{\mathrm{T} 7} p m r A$-His6 & Wösten and Groisman 1999 \\
\hline pT7-7-PmrAD51A-His6 & $\operatorname{rep}_{\mathrm{pMB} 1} \mathrm{Ap}^{\mathrm{R}} \mathrm{p}_{\mathrm{T} 7}$ pmrAD51A-His6 & This work \\
\hline pT7-7-PmrA505-His6 & $\mathrm{rep}_{\mathrm{pMB} 1} \mathrm{AP}^{\mathrm{R}} \mathrm{p}_{\mathrm{T} 7}$ pmrA505-His6 & This work \\
\hline pT7-7-YgiX-His6 & $\operatorname{rep}_{\mathrm{pMB} 1} \mathrm{Ap}^{\mathrm{R}} \mathrm{p}_{\mathrm{T} 7}$ ygiX-His6 & This work \\
\hline pT7-7-AX-His6 & $\operatorname{rep}_{\mathrm{pMB} 1} \mathrm{Ap}^{\mathrm{R}} \mathrm{p}_{\mathrm{T} 7} p m r A-y g i X$-His 6 & This work \\
\hline pT7-7-XA-His6 & $\operatorname{rep}_{\mathrm{pMB} 1} \mathrm{Ap}^{\mathrm{R}} \mathrm{p}_{\mathrm{T} 7}$ ygiX-pmrA-His6 & This work \\
\hline pT7-7-His6-PmrB & $\operatorname{rep}_{\mathrm{pMB} 1} \mathrm{Ap}^{\mathrm{R}} \mathrm{p}_{\mathrm{T} 7}$ His6- $p m r B_{c}$ & Wösten and Groisman 1999 \\
\hline pT7-7-His6-PmrB T156R & $\operatorname{rep}_{\mathrm{pMB} 1} \mathrm{Ap}^{\mathrm{R}} \mathrm{p}_{\mathrm{T} 7}$ His6-pmrB $B_{c} \mathrm{~T} 156 \mathrm{R}$ & This work \\
\hline pT7-7-His6-YgiY & $\operatorname{rep}_{\mathrm{pMB} 1} \mathrm{Ap}^{\mathrm{R}} \mathrm{p}_{\mathrm{T} 7}$ His6-ygi $Y_{c}$ & This work \\
\hline pGEX-2T & $\operatorname{rep}_{\mathrm{pMB} 1} \mathrm{Ap}^{\mathrm{R}} \mathrm{p}_{t a c} \mathrm{GST}$ & Amersham Biosciences \\
\hline pGEX-PmrB ${ }_{c}$ T156R & $\operatorname{rep}_{\mathrm{pMB} 1} \mathrm{Ap}^{\mathrm{R}} \mathrm{p}_{t a c}$ GST-pmrB ${ }_{c} \mathrm{~T} 156 \mathrm{R}$ & Kato et al. 2003 \\
\hline pGEX-YgiY $_{c}$ & $\operatorname{rep}_{\mathrm{pMB} 1} \mathrm{Ap}^{\mathrm{R}} \mathrm{p}_{t a c} \mathrm{GST}-y g i Y_{c}$ & This work \\
\hline
\end{tabular}

TTCACCCTGACCGCTGGCGCGGCGTACC-3'), and 2395 instead of 2453, 2340, 2339, and 2432. The resulting PCR fragment was digested with NdeI and HindIII and ligated to pT7-7 plasmid DNA that had been digested with NdeI and HindIII.
Plasmid pT7-7-His6-PmrB ${ }_{\mathrm{c}}$ T156R encodes a mutant PmrB cytoplasmic domain with the T156R substitution, which is crucial for phosphatase activity in the sensor EnvZ of E. coli (Dutta et al. 2000). It was constructed by cloning between the NdeI and 
HindIII sites of the pT7-7 plasmid a PCR fragment containing the $p m r B_{c}$ T156R coding region amplified using primers 988 (5'-AGATATACATATGCACCACCACCACCACCACCGGC GTATTACCCGTCCGCTC-3') and 1232 (5'-ACGAAGCTTAT GCCTTTTTCA-3') and pCCR9-pmrBT156R as template, and digested with NdeI and HindIII.

Plasmid pGEX-YgiY $\mathrm{c}_{\mathrm{c}}$ encoding an $\mathrm{N}$-terminal GST fusion of the YgiY cytoplasmic domain, was constructed by cloning between the BamHI and EcoRI sites of pGEX-2T a PCR fragment containing the ygi $Y_{C}$ coding region amplified using primers 2543 (5'-CGGGATCCCACCGCGAGCTCAGACCATT-3') and 2544 (5'-GGAATTCTTACCAACTTACTACGGCCT-3') and $\mathrm{pUH}$-ygiXY as template, and digested with BamHI and EcoRI.

All PCR reactions were performed using Platinum Taq DNA polymerase high fidelity (Invitrogen), which minimizes the production of DNA fragments with heterogeneous ends because of its 3'-to-5' exonuclease activity. All plasmids constructed using PCR reactions were analyzed by DNA sequencing, and we confirmed that the DNA regions generated by PCR had the predicted sequences and no unexpected substitutions.

\section{Construction of chromosomal gene deletion mutants}

Strains EG13732 and EG13831, which have a deletion in the pmrB gene, were constructed by the one-step gene inactivation method (Datsenko and Wanner 2000). A Km ${ }^{\mathrm{R}}$ cassette was amplified using primers 2124 (5'-CTACATGCTGGTTGCCACT GAGGAAAGCTAAGTGAGCCTGGTGTAGGCTGGAGCT GCTTC- $\left.3^{\prime}\right)$ and $1583\left(5^{\prime}\right.$-TTTATCTATGTGTGGGTCACGA CGTATTAAACGCCTGTTACATATGAATATCCTCCTTAG$\left.3^{\prime}\right)$ and pKD4 as template and recombined into the $p m r B$ region in strains 14028s and EG9492, respectively. The $\mathrm{Km}^{\mathrm{R}}$ cassette was removed by using plasmid pCP20 as described (Datsenko and Wanner 2000).

Strain EG14089, which has a deletion of the $p m r D$ gene, was constructed as follows: $\mathrm{A} \mathrm{Cm}^{\mathrm{R}}$ cassette was amplified using primers 1485 (5'-GTGTAACGTGTTATGAACAATCAGCGT GAAACGGGGGCGCTGTAGGCTGGAGCTGCTTCG-3') and 1486 (5'-TTATGGCGGGGGTAATGCTGATTTTTCTGCCC GCCAGATCACATATGAATATCCTCCTTAG-3') and pKD3 as template, and recombined into the $\mathrm{pmrD}$ region in the strain 14028s. The $\mathrm{Cm}^{\mathrm{R}}$ cassette was removed using plasmid pCP20.

E. coli strain EG13796, which has a deletion in the pmrAB orthologs basRS genes, was constructed by one-step gene inactivation method. A Cm${ }^{\mathrm{R}}$ cassette was amplified using primers 2116 (5'-CTGCGGATGATATTCTGCAAACTTGCAGGAGA GTGAGTGATGTAGGCTGGAGCTGCTTCG-3') and 2115 (5'-CTACCGTGTTCAGCGTGCTGGTGGTCAGCAGCTTT CTTTACATATGAATATCCTCCTTAG-3') and pKD3 as template, and recombined into the basRS region of strain ER2566.

\section{Overproduction and purification of proteins}

The PmrA, PmrAD51A, PmrA505, PmrB ${ }_{c}, P_{r} B_{c}$ T156R, YgiX, $\mathrm{YgiY}_{\mathrm{c}}$, and the chimeric proteins PmrA-YgiX and YgiX-PmrA were overproduced in E. coli EG13796 harboring pT7-7-PmrAHis6, pT7-7-PmrAD51A-His6, pT7-7-PmrA505-His6, pT7-7His6-PmrB ${ }_{c}$ pT7-7-His6-PmrB ${ }_{c}$ T156R, pT7-7-YgiX-His6, pT77-His6-YgiY ${ }_{c}$ pT7-7-AX-His6, and pT7-7-XA-His6, respectively. The conditions for expression of His6-tagged proteins were incubation with IPTG (final concentration $1 \mathrm{mM}$ ) for $3 \mathrm{~h}$ at $30^{\circ} \mathrm{C}$. Protein purification was performed as described (Kato et al. 2003) with the modifications described below. After purification, the buffer of the eluate was exchanged with $10 \mathrm{mM}$ Tris- $\mathrm{HCl}$ (pH 7.5)/138 mM NaCl/2.7 mM KCl (TBS) and concen- trated using Amicon Ultra-15 (MW 10,000; Millipore). Glycerol was added to the protein solution to a $50 \%$ final concentration, and it was stored at $-20^{\circ} \mathrm{C}$.

The purification of the glutathione Sepharose beads bound to the GST-YgiY ${ }_{c}$ and GST-PmrB ${ }_{\mathrm{c}}$ T156R proteins was performed as described for GST-PmrB ${ }_{\mathrm{c}}$ T156R (Kato et al. 2003) with the modifications described below. The GST-YgiY $\mathrm{c}_{\mathrm{c}}$ and GST$\mathrm{PmrB}_{\mathrm{c}} \mathrm{T156R}$ proteins were overproduced in E. coli strain EG13796 harboring pGEX-YgiY ${ }_{c}$ and pGEX-PmrB ${ }_{c}$ T156R, respectively. The glutathione Sepharose beads-bound GST-YgiY and GST-PmrB ${ }_{\mathrm{c}}$ T156R proteins were stored in $1 / 2 \mathrm{TBS} / 50 \%$ glycerol at $-20^{\circ} \mathrm{C}$.

The Intein-PmrD-Flag protein was overproduced in E. coli strains ER2566 or EG13796 harboring pTYB11-PmrD-Flag. The conditions for expression of Intein-PmrD-Flag protein were induction with IPTG (final concentration $300 \mu \mathrm{M}$ ) in $4 \mathrm{~L}$ of LB for $20 \mathrm{~h}$ at $15^{\circ} \mathrm{C}$. Autocleavage and purification of the PmrD-Flag protein was performed following the manufacturer's procedure (New England Biolabs). The conditions for autocleavage were incubation with $20 \mathrm{mM}$ Na-phosphate buffer $(\mathrm{pH} 8.0) / 300 \mathrm{mM}$ $\mathrm{NaCl} / 50 \mathrm{mM}$ DTT for $2 \mathrm{~d}$ at $4^{\circ} \mathrm{C}$ followed by $1 \mathrm{~d}$ at room temperature. After purification, the buffer of the eluate was exchanged with $20 \mathrm{mM}$ Na-phosphate buffer $(\mathrm{pH} 8.0) / 300 \mathrm{mM}$ $\mathrm{NaCl}$ and concentrated using Amicon Centriprep YM-3 (MW 3000; Millipore). Glycerol was added to the protein solution at $50 \%$ final concentration, and it was stored at $-20^{\circ} \mathrm{C}$.

\section{Autokinase assay}

The His6-PmrB ${ }_{c}(2.5 \mu \mathrm{M})$ and PmrD-Flag $(5 \mu \mathrm{M})$ proteins were incubated with $3.75 \mu \mathrm{Ci}\left[\gamma^{-32} \mathrm{P}\right] \mathrm{ATP}(3000 \mathrm{Ci} / \mathrm{mmole})$ in $30 \mu \mathrm{L}$ of TBS/ $1 \mathrm{mM} \mathrm{MgCl}_{2} / 1 \mathrm{mM}$ DTT at room temperature. The reaction was started with addition of the histidine kinase to the mixture. A $10-\mu \mathrm{L}$ aliquot was then mixed with $4 \times$ SDS sample buffer to stop the reaction at different time points. Samples were kept on ice until the performance of SDS-PAGE. After electrophoresis, the gel was autoradiographed.

\section{Phosphotransfer assay}

To obtain phospho-His6- $\mathrm{PmrB}_{\mathrm{c}}$ protein, the His6- $\mathrm{PmrB}_{\mathrm{c}}$ protein $(5 \mu \mathrm{M})$ was preincubated with $20 \mu \mathrm{Ci}\left[\gamma^{-32} \mathrm{P}\right]$ ATP in $80 \mu \mathrm{L}$ of TBS/ $1 \mathrm{mM} \mathrm{MgCl} / 1 \mathrm{mM}$ DTT for $1 \mathrm{~h}$ at room temperature. After chilling the reaction on ice, $5 \mu \mathrm{L}$ was mixed with $4 \times$ SDS sample buffer and kept as a reference sample for the phospho$\mathrm{PmrB}_{\mathrm{c}}$ protein before the phosphotransfer reaction. Thirty microliters of phospho-His6- $\mathrm{PmrB}_{\mathrm{c}}$ protein mixture was added into $30 \mu \mathrm{L}$ of TBS $/ 1 \mathrm{mM} \mathrm{MgCl}_{2} / 1 \mathrm{mM}$ DTT containing $10 \mu \mathrm{M}$ response regulator proteins (i.e., PmrA-His6 and PmrAD51AHis6) to initiate the phosphotransfer reaction and incubated at room temperature. A $10-\mu \mathrm{L}$ aliquot was then mixed with $4 \times$ SDS sample buffer to stop the reaction at different time points. Samples were kept on ice until SDS-PAGE. After electrophoresis, the gel was autoradiographed.

\section{Kinase/phosphatase assay}

Five micromolar response regulator proteins (i.e., PmrA-His6 and YgiX-His6), $2.5 \mu \mathrm{M}$ histidine kinase protein (i.e., His6$\mathrm{PmrB}_{\mathrm{c}}$, His6-YgiY $\mathrm{c}_{\mathrm{c}}$ and His6-PmrB $\left.\mathrm{c} 156 \mathrm{R}\right)$, and $5 \mu \mathrm{M}$ PmrDFlag protein were incubated with $3.75 \mu \mathrm{Ci}\left[\gamma^{32} \mathrm{P}\right] \mathrm{ATP}$ in $30 \mu \mathrm{L}$ of TBS/ $1 \mathrm{mM} \mathrm{MgCl}_{2} / 1 \mathrm{mM} \mathrm{DTT}$ at room temperature. The reaction was started with addition of histidine kinase to the mixture. A $10-\mu \mathrm{L}$ aliquot was then mixed with $4 \times$ SDS sample buffer to stop the reaction at different time points. Samples 
were kept on ice until SDS-PAGE. After electrophoresis, the gel was autoradiographed.

\section{Phosphatase assay}

To generate substrates for the phosphatase assay, phosphorylated response regulator proteins (i.e., phospho-PmrA-His6, phospho-PmrA505-His6, phospho-YgiX-His6, phospho-PmrAYgiX-His6, and phospho-YgiX-PmrA-His6) were prepared as follows: First, 0.3 nmole of GST-PmrB ${ }_{\mathrm{c}}$ T156R or GST-YgiY beads were incubated with $5 \mu \mathrm{Ci}\left[\gamma_{32} \mathrm{P}\right]$ ATP in $60 \mu \mathrm{L}$ of TBS/1 mM $\mathrm{MgCl}_{2} / 1 \mathrm{mM}$ DTT for $16 \mathrm{~h}$ at room temperature, and then washed with TBS three times to remove free ATP. Three nanomoles of response regulator protein was incubated with phosphorylated GST-PmrB $\mathrm{c}_{\mathrm{c}}$ T156R or GST-YgiY $\mathrm{c}_{\mathrm{c}}$ beads in $50 \mu \mathrm{L}$ of TBS/ $1 \mathrm{mM} \mathrm{MgCl}_{2} / 1 \mathrm{mM}$ DTT for $4 \mathrm{~h}$ at room temperature. After the incubation, GST-fusion protein beads were spun down and removed. Possible trace amounts of ATP contaminant were removed from phosphorylated response regulator fraction using a Micro Bio-Spin 6 Chromatography Column (Bio-Rad) which had been pre-equilibrated with TBS.

Phosphorylated response regulator protein $(2.5 \mu \mathrm{M})$, histidine kinase protein $\left(\right.$ His6-PmrB $_{\mathrm{c}}$ His6-PmrB $\mathrm{P}_{\mathrm{c}} \mathrm{T156R}$, and His6$\left.\mathrm{YgiY}_{\mathrm{c}} 5 \mu \mathrm{M}\right)$, and PmrD-Flag $(2.5 \mu \mathrm{M})$ protein were incubated in $35 \mu \mathrm{L}$ of TBS/ $1 \mathrm{mM} \mathrm{MgCl}_{2} / 1 \mathrm{mM}$ DTT at room temperature. The reaction was started by addition of phosphorylated response regulator to the mixture. A $10-\mu \mathrm{L}$ aliquot was then mixed with $4 \times$ SDS sample buffer to stop the reaction at the indicated time points. Samples were kept on ice until SDS-PAGE. After electrophoresis, the gel was autoradiographed.

Quantitative analysis of ${ }^{32} \mathrm{P}$-labeled phosphorylated response regulator was carried out using a BAS-MS 3543 imaging plate and an FLA-5000 imaging system (Fuji Film).

\section{Immunoprecipitation analysis}

Two micromolar response regulator proteins (i.e., PmrA-His6, YgiX-His6, PmrA-YgiX-His6, and YgiX-PmrA-His6), $2 \mu \mathrm{M}$ histidine kinase protein (i.e., His6-PmrB ${ }_{c}$, His6-YgiY ${ }_{c}$ ), and $1 \mu \mathrm{M}$ PmrD-Flag protein were incubated in $120 \mu \mathrm{L}$ of TBS/0.2 mM $\mathrm{ATP} / 1 \mathrm{mM} \mathrm{MgCl}_{2} / 1 \mathrm{mM} \mathrm{DTT}$ for $16 \mathrm{~h}$ at room temperature. After the reaction, the mixture was chilled on ice, and $20 \mu \mathrm{L}$ aliquot was removed and kept as a preimmunoprecipitation (pre-IP) sample; $900 \mu \mathrm{L}$ of $10 \mathrm{mM}$ Tris- $\mathrm{HCl}(\mathrm{pH} 7.5) / 1 \mathrm{M} \mathrm{NaCl} /$ $2.7 \mathrm{mM} \mathrm{KCl} / 1 \%$ Triton X-100 (IP-washing buffer) and $10 \mu \mathrm{L}$ of $50 \%$ EZview Red anti-Flag M2 Affinity Gel (Sigma), which had been pre-equilibrated with IP-washing buffer, were added and agitated gently for $1 \mathrm{~h}$ at $4^{\circ} \mathrm{C}$. Unbound proteins were removed by a centrifugation for $30 \mathrm{sec}$ at 8200 relative centrifugal force. The beads that bound proteins were extensively washed with $500 \mu \mathrm{L}$ of IP-washing buffer four times and with $500 \mu \mathrm{L}$ of TBS/ $1 \%$ Triton X-100 twice, and then incubated with $20 \mu \mathrm{L}$ of TBS/ $1 \%$ Triton X-100/Flag peptide $(200 \mu \mathrm{g} / \mu \mathrm{L})$ for $30 \mathrm{~min}$ at $4^{\circ} \mathrm{C}$ to elute specifically bound proteins. The beads were spun down and removed. A $10-\mu \mathrm{L}$ aliquot was mixed with $4 \times$ SDS sample buffer and kept on ice until SDS-PAGE. After electrophoresis, the gel was silver-stained.

To visualize phosphorylated proteins, $12 \mu \mathrm{Ci}\left[\gamma_{-}{ }^{32} \mathrm{P}\right] \mathrm{ATP}$ was used for the phosphorylation reaction instead of cold ATP and incubated for $4 \mathrm{~h}$ at room temperature before immunoprecipitation analysis. After electrophoresis, the gel was autoradiographed.

\section{S1 nuclease and $\beta$-galactosidase assays}

The S1 nuclease protection assay was performed as described (Kato et al. 2003) with RNA from early-exponential (O.D. ${ }_{600}$ : 0.2-0.3)-phase cultures grown in $25 \mathrm{~mL} \mathrm{~N}$-minimal medium at $\mathrm{pH}$ 7.7, with $10 \mathrm{mM} \mathrm{MgCl}_{2}, 10 \mu \mathrm{M} \mathrm{MgCl}_{2}, 10 \mathrm{mM}$ and $100 \mu \mathrm{M}$ $\mathrm{FeCl}_{3}$, or $10 \mu \mathrm{M} \mathrm{MgCl}_{2}$ and $100 \mu \mathrm{M} \mathrm{FeCl}_{3}$. $\beta$-galactosidase assays were carried out in triplicate, and the activity was determined as described (Miller 1972). Bacteria from overnight cultures grown in $\mathrm{N}$-minimal medium at $\mathrm{pH} 7.7$ with $10 \mathrm{mM}$ $\mathrm{MgCl}_{2}$ were washed three times with $\mathrm{N}$-minimal medium containing no $\mathrm{Mg}^{2+}$, and added into the appropriate fresh media with $50 \times$ dilution. The bacterial cultures were shaken for $4 \mathrm{~h}$ at $37^{\circ} \mathrm{C}$ before the assay. Data correspond to mean values of three independent experiments performed in duplicate.

\section{Western blot analysis}

Bacteria were grown as described in $\beta$-galactosidase assays. Bacterial cells were collected from $3-\mathrm{mL}$ cultures and resuspended in an appropriate volume of B-PER (Pierce). Whole-cell lysate (20 $\mu \mathrm{g}$ of protein) was run on a Bis-Tris $10 \%$ gel (Invitrogen) with MOPS SDS Running buffer, transferred to nitrocellulose membrane, and analyzed by Western blot using anti-PmrA or anti$\mathrm{PmrB}_{\mathrm{c}}$ polyclonal antibodies. Western blots were developed by using anti-rabbit IgG horseradish peroxidase-linked antibodies (Amersham Biosciences) and Supersignal west femto (Pierce).

\section{Acknowledgments}

We thank F. Solomon, T. Latifi, and M. Cromie for technical assistance; H. Huang, P.W. Majerus, J.D. York, D. Reinberg, J. Heitman, Y. Shi, S. Chamnongpol, J. Bijlsma, and M. Winfield for discussions; and H. Huang, M. Winfield, and D. Shin for comments on the manuscript. This work was supported in part by grant 42336 from NIH to E.A.G., an Investigator of the Howard Hughes Medical Institute.

\section{References}

Atkinson, M.R., Kamberov, E.S., Weiss, R.L., and Ninfa, A.J. 1994. Reversible uridylylation of the Escherichia coli PII signal transduction protein regulates its ability to stimulate the dephosphorylation of the transcription factor nitrogen regulator I (NRI or NtrC). J. Biol. Chem. 269: 28288-28293.

Bijlsma, J.J. and Groisman, E.A. 2003. Making informed decisions: Regulatory interactions between two-component systems. Trends Microbiol. 11: 359-366.

Burkholder, W.F., Kurtser, I., and Grossman, A.D. 2001. Replication initiation proteins regulate a developmental checkpoint in Bacillus subtilis. Cell 104: 269-279.

Cherepanov, P.P. and Wackernagel, W. 1995. Gene disruption in Escherichia coli: TcR and KmR cassettes with the option of Flp-catalyzed excision of the antibiotic-resistance determinant. Gene 158: 9-14.

Datsenko, K.A. and Wanner, B.L. 2000. One-step inactivation of chromosomal genes in Escherichia coli K-12 using PCR products. Proc. Nat1. Acad. Sci. 97: 6640-6645.

Davis, R.W., Bolstein, D., and Roth, J.R. 1980. Advanced bacterial genetics. Cold Spring Harbor Laboratory, Cold Spring Harbor, NY.

Dutta, R., Yoshida, T., and Inouye, M. 2000. The critical role of the conserved Thr247 residue in the functioning of the osmosensor EnvZ, a histidine Kinase/Phosphatase, in Escherichia coli. J. Biol. Chem. 275: 38645-38653.

Fields, P.I., Swanson, R.V., Haidaris, C.G., and Heffron, F. 1986. Mutants of Salmonella typhimurium that cannot survive within the macrophage are avirulent. Proc. Natl. Acad. Sci. 83: 5189-5193. 
García Véscovi, E., Soncini, F.C., and Groisman, E.A. 1996. $\mathrm{Mg}^{2+}$ as an extracellular signal: Environmental regulation of Salmonella virulence. Cell 84: 165-174.

Groisman, E.A., Kayser, J., and Soncini, F.C. 1997. Regulation of polymyxin resistance and adaptation to low- $\mathrm{Mg}^{2+}$ environments. J. Bacteriol 179: 7040-7045.

Gunn, J.S. and Miller, S.I. 1996. PhoP-PhoQ activates transcription of pmrAB, encoding a two-component regulatory system involved in Salmonella typhimurium antimicrobial peptide resistance. J. Bacteriol. 178: 6857-6864.

Hanahan, D. 1983. Studies on transformation of Escherichia coli with plasmids. J. Mol. Biol. 166: 557-580.

Hoch, J.A. and Silhavy, T.J. 1995. Two-component signal transduction. ASM Press, Washington, DC.

Inouye, M. and Dutta, R. 2003. Histidine kinases in signal transduction. Academic Press, San Diego.

Jiang, P. and Ninfa, A.J. 1999. Regulation of autophosphorylation of Escherichia coli nitrogen regulator II by the PII signal transduction protein. J. Bacteriol. 181: 1906-1911.

Jiang, P., Peliska, J.A., and Ninfa, A.J. 1998. Enzymological characterization of the signal-transducing uridylyltransferase/ uridylyl-removing enzyme (EC 2.7.7.59) of Escherichia coli and its interaction with the PII protein. Biochemistry 37: 12782-12794.

Kato, A., Latify, T., and Groisman, E.A. 2003. Closing the loop: The PmrA/PmrB two-component system negatively controls expression of its posttranscriptional activator PmrD. Proc. Natl. Acad. Sci. 100: 4706-4711.

Kox, L.F., Wosten, M.M., and Groisman, E.A. 2000. A small protein that mediates the activation of a two-component system by another two-component system. EMBO $I$. 19: 1861-1872.

Lee, H., Hsu, F.F., Turk, J., and Groisman, E.A. 2004. The PmrAregulated pmrC gene mediates phosphoethanolamine modification of lipid A and polymyxin resistance in Salmonella enterica. J. Bacteriol. 186: 4124-4133.

Miller, J.H. 1972. Experiments in molecular genetics. Cold Spring Harbor Laboratory Press, Cold Spring Harbor, NY.

Obsil, T., Ghirlando, R., Klein, D.C., Ganguly, S., and Dyda, F. 2001. Crystal structure of the 14-3-3\%:serotonin N-acetyltransferase complex. a role for scaffolding in enzyme regulation. Cell 105: 257-267.

Pawson, T. and Nash, P. 2003. Assembly of cell regulatory systems through protein interaction domains. Science 300: 445452.

Perego, M. 1998. Kinase-phosphatase competition regulates $\mathrm{Ba}$ cillus subtilis development. Trends Microbiol. 6: 366-370.

Perego, M. and Hoch, J.A. 1996. Protein aspartate phosphatases control the output of two-component signal transduction systems. Trends Genet. 12: 97-101.

Perego, M., Hanstein, C., Welsh, K.M., Djavakhishvili, T., Glaser, P., and Hoch, J.A. 1994. Multiple protein-aspartate phosphatases provide a mechanism for the integration of diverse signals in the control of development in B. subtilis. Cell 79: $1047-1055$.

Pioszak, A.A., Jiang, P., and Ninfa, A.J. 2000. The Escherichia coli PII signal transduction protein regulates the activities of the two-component system transmitter protein NRII by direct interaction with the kinase domain of the transmitter module. Biochemistry 39: 13450-13461.

Randegger, C.C., Keller, A., Irla, M., Wada, A., and Hächler, H. 2000. Contribution of natural amino acid substitution in SHV extended-spectrum $\beta$-lactams. Antimicrob. Agents Chemother. 44: 2759-2763.

Roland, K.L., Martin, L.E., Esther, C.R., and Spitznagel, J.K. 1993. Spontaneous pmrA mutants of Salmonella typhimu- rium LT2 define a new two-component regulatory system with possible role in virulence. J. Bacteriol. 175: 4154-4164.

Rowland, S.L., Burkholder, W.F., Cunningham, K.A., Maciejewski, M.W., Grossman, A.D., and King, G.F. 2004. Structure and mechanism of action of Sda, an inhibitor of the histidine kinases that regulate initiation of sporulation in Bacillus subtilis. Mol Cell 13: 689-701.

Sambrook, J., Fritsch, E.F., and Maniatis, T. 1989. Molecular cloning: A laboratory manual. Cold Spring Harbor Laboratory Press, Cold Spring Harbor, NY.

Snavely, M.D., Miller, C.G., and Maguire, M.E. 1991. The mgtB $\mathrm{Mg}^{2+}$ transport locus of Salmonella typhimurium encodes a P-type ATPase. J. Biol. Chem. 266: 815-823.

Soncini, F.C. and Groisman, E.A. 1996. Two-component regulatory systems can interact to process multiple environmental signals. J. Bacteriol. 178: 6796-6801.

Soncini, F.C., García Véscovi, E., and Groisman, E.A. 1995. Transcriptional autoregulation of the Salmonella typhimurium phoPQ operon. J. Bacteriol. 177: 4364-4371.

Stock, A.M., Robinson, V.L., and Goudreau, P.N. 2000. Twocomponent signal transduction. Annu. Rev. Biochem. 69: 183-215.

Tabor, S. and Richardson, C.C. 1985. A bacteriophage T7 RNA polymerase/promoter system for controlled exclusive expression of specific genes. Proc. Natl. Acad. Sci. 82: 10741078.

Tzivion, G. and Avruch, J. 2002. 14-3-3 proteins: Active cofactors in cellular regulation by serine/threonine phosphorylation. J. Biol. Chem. 277: 3061-3064.

Wang, L., Grau, R., Perego, M., and Hoch, J.A. 1997. A novel histidine kinase inhibitor regulating development in Bacillus subtilis. Genes \& Dev. 11: 2569-2579.

Wösten, M.M.S.M. and Groisman, E.A. 1999. Molecular characterization of the PmrA regulon. J. Biol. Chem. 274: 2718527190.

Wösten, M.M.S.M., Kox, L.F., Chamnongpol, S., Soncini, F.C., and Groisman, E.A. 2000. A signal transduction system that responds to extracellular iron. Cell 103: 113-125.

Yaffe, M.B. and Smerdon, S.J. 2001. Phosphoserine/threonine binding domains: You can't pSERious? Structure (Camb.) 9: R33-R38.

Yaffe, M.B., Rittinger, K., Volinia, S., Caron, P.R., Aitken, A., Leffers, H., Gamblin, S.J., Smerdon, S.J., and Cantley, L.C. 1997. The structural basis for 14-3-3:phosphopeptide binding specificity. Cell 91: 961-971. 


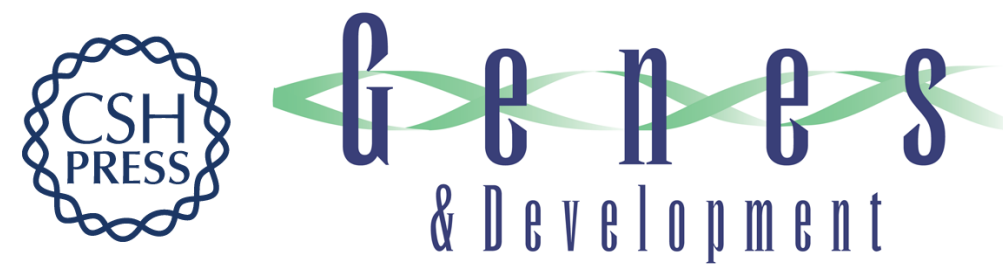

\section{Connecting two-component regulatory systems by a protein that protects a response regulator from dephosphorylation by its cognate sensor}

Akinori Kato and Eduardo A. Groisman

Genes Dev. 2004, 18:

Access the most recent version at doi:10.1101/gad.1230804

Supplemental http://genesdev.cshlp.org/content/suppl/2004/09/03/18.18.2302.DC1

Material

References This article cites 35 articles, 20 of which can be accessed free at:

http://genesdev.cshlp.org/content/18/18/2302.full.html\#ref-list-1

License

Email Alerting Receive free email alerts when new articles cite this article - sign up in the box at the top

Service right corner of the article or click here.

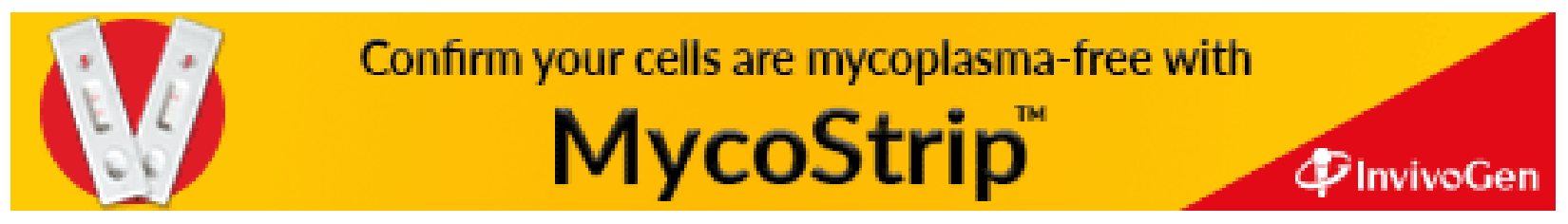

